\title{
In vitro trypanocidal activity of solamargine and extracts from Solanum palinacanthum and Solanum lycocarpum of brazilian cerrado
}

\author{
RAQUEL R.D. MOREIRA ${ }^{1}$, GILMARCIO Z. MARTINS ${ }^{1}$, NATHÁLIA O. MAGALHÃES ${ }^{1}$, ADÉLIA E. ALMEIDA ${ }^{2}$, \\ ROSEMEIRE C.L.R. PIETRO ${ }^{2}$, FLÁVIA A. J. SILVA and REGINA M.B. CICARELLI ${ }^{3}$ \\ ${ }^{1}$ Departamento de Princípios Ativos Naturais e Toxicologia, Faculdade de Ciências Farmacêuticas, \\ Universidade Estadual Paulista/UNESP, Rodovia Araraquara - Jaú, Km 1, s/n, 14801-502 Araraquara, SP, Brasil \\ ${ }^{2}$ Departamento de Fármacos e Medicamentos, Faculdade de Ciências Farmacêuticas, \\ Universidade Estadual Paulista/UNESP, Rodovia Araraquara - Jaú, Km 1, s/n, 14801-502 Araraquara, SP, Brasil \\ ${ }^{3}$ Departamento de Ciências Biológicas, Faculdade de Ciências Farmacêuticas, \\ Universidade Estadual Paulista/UNESP, Rodovia Araraquara - Jaú, Km 1, s/n, 14801-502 Araraquara, SP, Brasil
}

Manuscript received on May 28, 2012; accepted for publication on September 28, 2012

\begin{abstract}
The present investigation was to evaluate the potential trypanocidal activity of crude ethanolic extract of the fruits of Solanum palinacanthum, Solanum lycocarpum and the glycoalcaloid, solamargine. $S$. palinacanthum and S. lycocarpum fruit powders were submitted to exhaustively extraction with $96 \%$ ethanol and solamargine were isolated from the extract of S. palinacanthum. Both extracts and solamargine were analysed for trypanocidal activity by using MTT colorimetric assay. Extracts of S. palinacanthum showed to be more active $\left(\mathrm{IC}_{50}=175.9 \mu \mathrm{g} \cdot \mathrm{ml}^{-1}\right)$ than S. lycocarpum $\left(\mathrm{IC}_{50}=194.7 \mu \mathrm{g} \cdot \mathrm{ml}^{-1}\right)$. Solamargine presented a strong activity $\left(\mathrm{IC}_{50}=15.3 \mu \mathrm{g} \cdot \mathrm{ml}^{-1}\right)$, which can explain the better activity of the both extracts. Benznidazol $\left(\mathrm{IC}_{50}=9.0 \mu \mathrm{g} \cdot \mathrm{ml}^{-1}\right)$ is the only drug used to treat Chagas' disease. These findings demonstrate for the first time that ethanol extracts obtained from both fruits of S. palinacanthum and S. lycocarpum and also solamargine have a potential anti-trypanosomal activity.
\end{abstract}

Key words: Solanum palinacanthum, Solanum lycocarpum, solamargine, epimastigote, antitrypanosomal activity, Trypanosoma cruzi.

\section{INTRODUCTION}

Solanum palinacanthum Dunal. and Solanum lycocarpum St. Hill are members of the Solanaceae family, found in tropical and temperate zones, including the Brazilian Cerrado. They have great importance for food and medicinal use (Blankemeyer et al. 1998, Almeida et al. 2010). The antiviral, diuretic, anti-spasmodic, anti-

Correspondence to: Raquel Regina Duarte Moreira

E-mail: moreirar@fcfar.unesp.br inflammatory and other properties of these plants have been intensively studied (Balasubramanian et al. 2007; as cited by Soares-Mota et al. 2009). However, attention has not been given for other healing properties.

Phytochemical studies revealed that polyphenols and glycoalcaloids, the most common elements obtained from some species of Solanum, which are secondary synthesized metabolites, seek protection against animals and insects because of 
their toxicity (Hall et al. 2006). Glycoalkaloids solamargine and solasonine were identified in various species of Solanaceae family, which have extensive anti-viral function (Hall et al. 2006, Sun et al. 2010). However, the trypanocidal effects of the glycoalkaloids and plants extracts have never been reported before. The aim of the present investigation is to evaluate the potential trypanocidal activity of $95 \%$ crude ethanol extracts of the fruits of $S$. palinacanthum, S. lycocarpum and solamargine isolated from S. palinacanthum, the major constituent of these plants.

\section{MATERIALS AND METHODS}

\section{Plant MATERIAL AND EXTRACTION}

The study was performed with fruits from a Solanum palinacanthum Dunal. and Solanum lycocarpum St. Hill collected in Itápolis and Barretos, respectively, cities within districts of São Paulo State, Brazil. The voucher specimen of $S$. palinacanthum Dunal. has been deposited at the Herbário do Instituto de Biociências of the Universidade Estadual Paulista (UNESP), Rio Claro, São Paulo State, Brazil; S. lycocarpum St. Hill has been deposited at the Herbário do Departamento de Biologia of the Faculdade de Filosofia Ciências e Letras de Ribeirão Preto of the Universidade de São Paulo (SPFR 11.308), Ribeirão Preto, São Paulo, Brazil. All fruits were dried in hot air flow at $60^{\circ} \mathrm{C}$ and then crushed in a blade grinder, to facilitate extraction of the chemical constituents.

Fruits powder $(500 \mathrm{~g})$ of $S$. palinacanthum were submitted to exhaustively extraction with $96 \%$ ethanol $(\mathrm{EtOH})$ by four times at temperature $(4 \mathrm{oC})$. The solvent proportion corresponded to five times the plant material. Subsequently, exhaustive extraction with hot $\mathrm{EtOH}$ was done and evaporation of the solvent under reduced pressure afforded a crude extract $(100.2 \mathrm{~g})$. The crude extract was redissolved in 5\% aqueous acetic acid (v/v) and after 24 hours, a preliminary purification involving defatting was done by successive benzene extraction. The final solution was changed to $\mathrm{pH}$ 10.0 with ammonium hydroxide. After 24 hours at room temperature the precipitated was obtained, filtered and dried (24.2 g).

Fruits powder (35 g) of Solanum lycocarpum was submitted to exhaustively extraction with $250 \mathrm{~mL}$ of $96 \%$ ethanol by 4 hours at boiling temperature, followed by filtration under reduced pressure. These processes were repeated with 200 $\mathrm{mL}$ of $96 \%$ ethanol. Were blended the extracts and concentrated under reduced pressure until syrupy consistency and then dried to room temperature by air suction (8.12 g) (Almeida et al. 1995).

ISOLATION AND IDENTIFICATION OF SOLAMARGINE

The glycoalkaloid mixture of Solanum palinacanthum was subjected to chromatographic column (aluminum oxide, neutral) and after elution with $40 \%$ aqueous ethanol $(\mathrm{v} / \mathrm{v})$ yielded solamargine $(0.92 \mathrm{~g})$ as showed in the Fig. 1. The separation was monitored by TLC in solvent system (n-butanol:acetic acid glacial:water (6:3:1), nebulized and developed with 10\% aqueous sulfuric acid $(\mathrm{v} / \mathrm{v})$ and then heated at $150{ }^{\circ} \mathrm{C}$ for $5 \mathrm{~min}$. Solamargine was obtained and rechromatographed on aluminum for purification and repeatedly recrystallised with methanol, and its identity ascertained by comparing physical and spectral data (mp, IV) (Almeida et al. 1995).

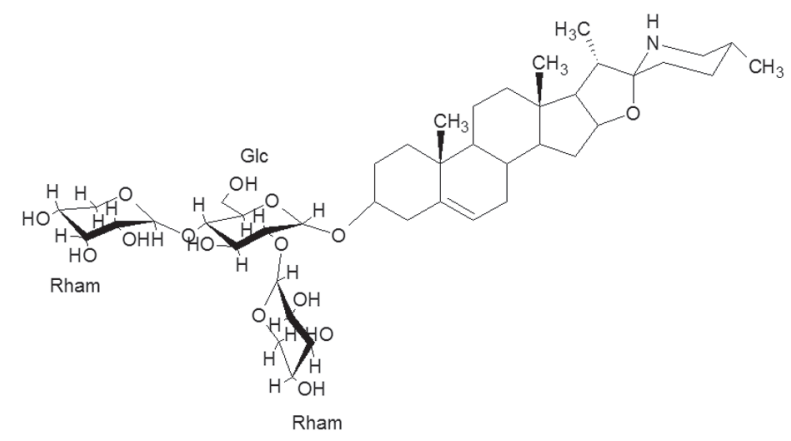

Figure 1 - Chemical structures of solamargine 


\section{TRYPANOCIDAL ACTIVITY-MTT ASSAY}

An in vitro assay was performed measuring the viability of Trypanosoma cruzi (Y strain) epimastigote forms growing in axenic culture using MTT assay (Cotinguiba et al. 2009). The parasites were grown axenically at $28{ }^{\circ} \mathrm{C}$ in liverinfusion Tryptose (LIT) medium supplemented with $10 \%$ fetal calf serum and harvested during the exponential phase of growth (7 day-old culture forms). Extracts and compounds were dissolved in dimethylsulfoxide (DMSO) and further added to a 96-well tissue culture plate (TPP) in different final concentrations. T. cruzi (1 x $10^{7}$ parasites. $\left.\mathrm{mL}^{-1}\right)$ were added into each well and the same quantity of LIT medium was added into the control wells. These plates were maintained at $28{ }^{\circ} \mathrm{C}$ for $72 \mathrm{~h}$, $10 \mu \mathrm{L}$ of a $2.5 \mathrm{mg} \cdot \mathrm{mL}^{-1}$ MTT-PMS solution was added to each well and the plates were incubated for $75 \mathrm{~min}$ in the dark at $28{ }^{\circ} \mathrm{C}$. A solution of $10 \%$ $(100 \mu \mathrm{L})$ of sodium dodecyl sulfate (SDS) was added to the anterior solution and maintained at room temperature and in the dark at $30 \mathrm{~min}$. The absorbance of the samples had read at $595 \mathrm{~nm}$. The $50 \%$ inhibitory concentration $\left(\mathrm{IC}_{50}\right)$ values were determined by linear regression analysis after a $72 \mathrm{~h}$ incubation period. All the tests were done in triplicates and the $\mathrm{IC}_{50}$ values of samples and benznidazole (positive control) were determined. For the statistical analysis, probit's method was employed (Muelas-Serrano et al. 2000).

\section{RESULTS AND DISCUSSION}

Chagas' disease or American trypanosomiasis caused by the protozoan flagellate $T$. cruzi, is an important public health problem in Latin America, affecting millions of people annually (SanchezBurgos et al. 2003). The most common treatment for this disease involves two drugs, benznidazole (A) and nifurtimox (B) (Fig. 2), which are active only during the acute and short-term chronic phases. Beznidazole (Rochagan ${ }^{\circledR} /$ Brazil and Radanil $^{\circledR} /$ Argentina) is now the only drug still available since the production of nifurtimox was discontinued. Besides developing severe side effects, narrow therapeutic windows, and variable drug susceptibilities among $T$. cruzi strains, result in low clinical efficacies for these 2-nitroimidazole (Coura and Castro 2002).

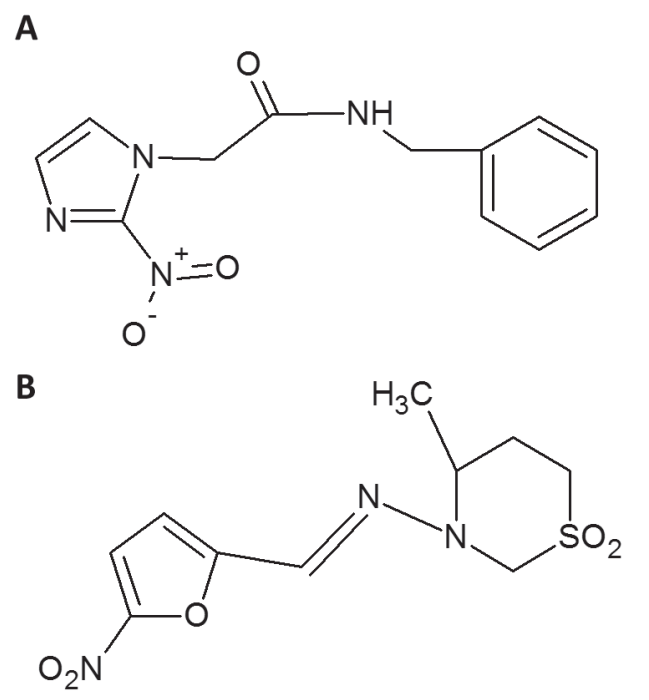

Figure 2 - Chemical structures of benznidazole (A) and nifurtimox (B)

In many Solanum species, the glycoalkaloids are presented as pairs of structurally related compounds which share a common aglycone with either solasodine and differ only in their carbohydrate moiety (Chataing et al. 1998). The literature contains several reports on the biological activity of nitrogen-containing steroids of the species Solanum (Chataing et al. 1998, Hall et al. 2006).

In this work, we presented the inhibitory activity the ethanol extracts from fruits of $S$. palinacanthum and S. lycocarpum, as well as the purified solamargine, comparing with benznidazole (as positive control). The results are shown in Table I.

The solamargine is a dominant steroidal glycoalkaloid extract from plants belonging to the genus Solanum and showed an $\mathrm{IC}_{50}$ very close to the benznidazole. Similar results were showed by other authors in the past (Chataing et al. 1998, Hall et al. 2006, Valaderesa et al. 2009). 
TABLE I

In vitro trypanocidal activity of ethanolic extracts of S. palinacanthum and S. lycocarpum and solamargine.

$\begin{array}{cc}\text { Compounds } & \mathbf{I C}_{\mathbf{5 0}}\left(\boldsymbol{\mu g} \cdot \mathbf{m L}^{\mathbf{- 1}}\right) \\ \text { extract of } S \text {. palinacanthum } & 175.9 \\ \text { extract of } S \text {. lycocarpum } & 194.7 \\ \text { solamargine } & 15.3 \\ \text { benznidazole* } & 9.0 \\ \text { * positive control. } & \end{array}$

There was a light difference in the response between the two extracts: $\mathrm{IC}_{50}=175.9 \mu \mathrm{g} \cdot \mathrm{ml}^{-1}$ for extract of $S$. palinacanthum and $\mathrm{IC}_{50}=194.7$ $\mu \mathrm{g} . \mathrm{ml}^{-1}$ for $S$. lycocarpum.

Solamargine isolated from $S$. palinacanthum showed an $\mathrm{IC}_{50}=15.3 \mu \mathrm{g} \cdot \mathrm{ml}^{-1}$, which was very interesting by explaining the better activity of the both extracts. Solamargine had also a pronounced effect on $\mathrm{T}$. cruzi, closely similar to benznidazole $\left(\mathrm{IC}_{50}=9.0 \mu \mathrm{g} \cdot \mathrm{ml}^{-1}\right)$. However, other methodologies should be used to rightly understand the mechanism of action.

Our results were very similar to those described by Hall et al. (2006), but using different approach. They have speculated that the positioning of the terminal sugars in $\alpha$-solamargine is sterically more favorable to bind with the parasites mucin-rich cell surface than those of $\alpha$-solasonine (Hall et al. 2006). Once bound in sufficient concentrations, the alkaloid's lipid moiety would induce cytolysis through hydrophobic interactions with membrane sterols (Hall et al. 2006).

Since the alkaloid used in this study was derived from ripe fruits of a Solanum species. There have been numerous hypotheses put forth to explain the allocation of secondary metabolites in ripe fleshy fruits (Hall et al. 2006, Li et al. 2007), including the retention of high levels of glycoalkaloids in fruits of some Solanum species (Kuo et al. 2000, Hall et al. 2006).

The $96 \%$ ethanolic extracts from the fruits of $S$. palinacanthum and S. lycocarpum exhibited the most potent in vitro trypanocidal activity. These species are an interesting group for more studies and search of novel therapeutic plants against Chagas' disease (Almeida et al. 1995; Soares-Mota et al. 2009).

\section{CONCLUSION}

It can be concluded from this study that 96\% ethanolic extracts from the fruits of $S$. palinacanthum and $S$. lycocarpum presented a potential anti-trypanosomal activity based on toxic effect against epimastigote form of $T$. cruzi Y strain. The glycoalkaloid solamargine has been isolated from $S$. palinacanthum and demonstrated to be active in the trypanocidal effect and would be a candidate to new therapeutic substance.

In view of these findings, further chemical and pharmacological investigations to identify others secondary metabolites and to evaluate the potential of these Solanum species as antichagasic agents in vivo are recommended.

\section{RESUMO}

O objetivo deste estudo foi avaliar a potencial atividade tripanocida do extrato bruto etanólico dos frutos de Solanum palinacanthum, Solanum lycocarpum e do glicoalcalóide solamargina. Pó do fruto seco de $S$. palinacanthum e $S$. lycocarpum foram submetidos a extracção por refluxo com etanol a $96 \%$ e solamargina foi isolada a partir do extrato bruto de S. palinacanthum. Foram determinadas de ambos os extratos e a solamargina a atividade tripanocida utilizando o ensaio colorimétrico MTT. O Extrato de $S$. palinacanthum mostrou-se mais ativo $\left(\mathrm{IC}_{50}=\right.$ $175,9 \mu \mathrm{g} \cdot \mathrm{ml}^{-1}$ ) de que o extrato de $S$. lycocarpum $\left(\mathrm{IC}_{50}=194,7 \mu \mathrm{g} \cdot \mathrm{ml}^{-1}\right)$. A solamargina apresentou forte atividade tripanocida $\left(\mathrm{IC}_{50}=15,3 \mu \mathrm{g} \cdot \mathrm{ml}^{-1}\right)$, o que pode explicar a melhor atividade de ambos os extratos. $\mathrm{O}$ benzonidazol $\left(\mathrm{IC}_{50}=9,0 \mu \mathrm{g} \cdot \mathrm{ml}^{-1}\right)$ é a única droga utilizada para o tratamento da doença de Chagas. Estes resultados demonstram pela primeira vez que os extratos etanólicos obtidos a partir de frutos de $S$. palinacanthum e $S$. lycocarpum, além da solamargina apresentam uma atividade tripanocida potencial. 
Palavras-chave: Solanum palinacanthum, Solanum lycocarpum, solamargina, epimastigota, atividade tripanocida, Trypanosoma cruzi.

\section{REFERENCES}

Almeida AE, CARdoso CRP, AlmeIDA DV, MOREIRA RRD, SiLVA M AND VARANDA EA. 2010. Mutagenic Activity of Glycoallkaloids from Solanum palinacanthum Dunal (Solanaceae) found in the Brazilian cerrado. Lat Am J Pharm 29: 122-126.

AlMEIDA AE AND RocCA MA. 1995. Glicoalcalóides dos frutos de Solanum flaccidum Vell. Rev Cienc Farm 16: 111-118.

Balasubramanian G, SARATHi M, Kumara SR AND HAMEED AS. 2007. Screening the antiviral activity of Indian medicinal plants against white spot syndrome virus in shrimp. Aquaculture 23: 15-19.

BLANKEMEYER JT, MCWILLIANS ML, RAYBURN JR, WeISSEnBERG M AND Friedman M. 1998. Developmental Toxicology of Solamargine and Solasonine Glycoalkaloids in Frog Embryos. Food Chem Toxicol 36: 383-389.

CHATAING B, CONCEPCIÓN JL, LOBATÓN R AND USUBILlAGA A. 1998. Inhibition of Trypanosoma cruzi Growth in vitro by Solanum alkaloids: A comparison with ketoconazole. Planta Medica 64: 31-36.

Cotinguiba F, Regasini LO, Bolzani VS, Debonsi HM, PASSERINI GD, CicARELli RMB, Kato MJ AND FurLAN M. 2009. Piperamides and their derivatives as potential anti-trypanosomal agents. Med Chem Res. Doi: 10.1007/ s00044-008-9161-9.

COURA JR AND CASTRO SL. 2002. A critical review on Chagas disease chemotherapy. Mem Inst Oswaldo Cruz 97: 3-24.

Hall CA, HobBy T AND Cipollini M. 2006. Efficacy and mechanisms of $\alpha$-solasonine and $\alpha$-solamargine-induced cytolysis on two strains of Trypanosoma cruzi. J Chemical Ecol 32: 2405-2416.
KuO KW, Hsu SH, Li YP, LIN WL, LIU LF, CHANG LC, LIN CC, LIN CN AND SHEU HM. 2000. Anticancer activity evaluation of the Solanum glycoalkaloid solamargine: Triggering apoptosis in human hepatoma cells. Biochem Pharmacol 60: 1865-1873.

Li S, HE DJ, ZANG X, Ni WH, ZHOU YF AND ZHANG LP. 2007. Modification of Sugar Chains in Glycoalkaloids and Variation of Anticancer Activity. Chem Res Chin Univ 23: 303-309.

Muelas-Serrano S, NOGAl-Ruiz J AND GómEZ-Barrio A. 2000. Setting of a colorimetric method to determine viability of Trypanosoma cruzi epimastigotes. Parasitol Res 86: 999-1002.

SAnchez-Burgos G, MezQuita-Veja RG, EscobedoORTEGON J, RAMIREZ-SIERRA MJ, ARJONA-TORRES A, OuAissi A, Rodrigues MM AND DuMONTEIL E. 2003. Comparative evaluation of therapeutic DNA vaccines against Trypanosoma cruzi in mice. FEMS Immunol Med Microbiol 50: 333-341.

SOARES-Mota MR, Schwars A, BERNARDI MM, MAIORKA PC AND SPINOSA HS. 2009. Toxicological evaluation of $10 \%$ Solanum lycocarpum St. Hill fruit consumption in the diet of growing rats: Hematologica, biochemical and histophatological effects. Exp Toxicol Pathol. Doi: 10.1016/j.etp.2009.07.006.

Sun F, Li S, He D, CAO G, Ni X, TAi G, Zhou Y AND Wang D. 2010. Effects of glycoalkaloids from Solanum plants on cucumber root growth. Phytochemistry. doi:10.1016/j. phytochem.2010.06.002.

VALADARESA YM, BRANDÃo GC, KROONB EG, SOUZA FILHO JD, OLIVEIRA AB AND BRAGA FC. 2009. Antiviral Activity of Solanum paniculatum Extract and Constituents. Z Naturforsch 64: 813-818. 